Ecem Karlidag-Dennis*, Simon McGrath, and Howard Stevenson School of Education, University of Nottingham, Nottingham, United Kingdom ecem.karlidag-dennis@northampton.ac.uk 


\section{Educational Policymaking and Hegemony: Monolithic Voices from Civil Society}

This article discusses the changes in basic education in Turkey, with a particular focus on religious education and its ramifications for the education system. The latest education reform, $4+4+4$ (or $4+$ ), the largest education reform in recent Turkish history, has brought radical changes to the school system regarding religious education. For this research, journalists and teacher unionists were interviewed to investigate civil society's perspective on the reform. Several themes were extracted from the data analysis but this article focuses on one dominant theme, namely the rise of religiosity. We argue that the state and its private associations (i.e., media, unions, and political parties) are actively encouraging a process of Islamisation and a gradual but stronger emphasis on Islam in public sphere in order to consolidate its hegemonic dominance.

Keywords: religion; Turkey; policymaking; media; teacher unions

\section{Introduction}

On $15^{\text {th }}$ of July 2016 , Turkey witnessed a coup attempt reportedly by the Gülenists, an international religious group led by a Turkish preacher living in the US. In its, aftermath, the Justice and Development Party (henceforth: JDP, in Turkish AKP: Adalet ve Kalkinma Partisi), who are currently in government, dismissed more than 100,000 public employees, including teachers and academics, due to their suspected involvement in the failed coup (New York Times 2016).

Two months later, the $19^{\text {th }}$ of September marked the first day of the new school year in Turkey. 18 million children started school and began their first class of the year with an introductory session about the failed coup attempt (Sabah 2016). Schools showed a documentary and the pupils received booklets about it, whilst some went further by staging reenactments of the coup day (Cumhuriyet 2016; Hürriyet 2016). Subsequently, the Ministry of National Education (MEB) announced that the coup would be included in national textbooks and curricula, and pupils would be expected to go on school trips to key coup locations (MEB 2016). Symbolically, this response to the failed coup is a vivid example of how education plays an essential part in the JDP government's leadership and how the education system has been directly affected by the political affairs of the country.

In this research, we argue that Turkey has been witnessing a return of religion both in political and civil society and that education is one of the main instruments being used to help bring about and consolidate this change. The aim of this article is to understand how the 4+ reforms seek to challenge the country's secularist tradition and shift the school system in favour of one based on religious principles through, for example, the active encouragement of new 
religious schools (imam hatip schools). By promoting religious education in this manner, the government appears both to be acting on genuine religious beliefs but is also deliberately seeking to use religion to consolidate popular support, especially amongst large sections of the population that are religiously more conservative. We also seek to demonstrate how the reforms have been contested within civil society, but how the government has been able co-opt key sections of the media and the teacher union movement in order to construct a broad hegemonic alliance.

This article begins with an overview of Islam's place in Turkey as part of a presentation of the wider context. The second section specifically focuses on the 4+ education reform and religious education in Turkey. It is followed by an explanation of the theoretical framework, which draws on Gramsci's concepts of hegemony and civil society. The fourth section then explains the research methods undertaken for this study. The final section evaluates the data from two key elements of civil society, teacher unions and the media, within a Gramscian framework. These groups' voices lead us to question whether the 4+, especially its provisions regarding religious education, contributes to an increased quality of education and redressing previous biases, as the JDP claims, or is better seen as a means of reinforcing the JDP's hegemonic leadership and, therefore, as a threat to the secular foundation of the state. Whilst this is not the first time Turkey has witnessed the rise of Islam in education and politics, the current approach is proving significantly more successful than previous attempts. Consequently, the questions this article addresses are: how is the 4+ education reform helping to establish an Islamic hegemony, and to what extent is civil society contributing to construction of this hegemony.

We argue that education is being used as part of a state apparatus to maintain the government's power and convey its ideology through the latest education reform. This leads us to investigate the role of civil society actors in this process. The research is significant due to its contribution to our understanding of how education plays an important part in shaping a country's future directions through its role in the formation of religious practices and discourses.

\section{Research Context:}

Islam has a long history in Turkey: from 1299 until the foundation of the Republic in 1923, the Ottoman Empire incorporated Islam in its state structure (Zurcher 2004). However, the successor regime, under Kemal Ataturk, was avowedly secularist, republican and modernising. Until 1946, the Turkish Republic was ruled by a single party, the RPP (the Republican People's Party). Even after the first multi-party elections, the RPP remained in power until 1950. In spite of this 27-year rule, the new secularist order did not remain in any way unchallenged, particularly in terms of support amongst the rural population (Nohl 2008). The May 1950 general elections saw the Democrat Party (DP) come to power. Whilst the DP did not challenge the Kemalist constitution, they drew much of their support from more rural areas and were somewhat less pro-Western and anti-Islamic than the RPP (Kaplan 2006). During the 1950s, the number of mosques and imam hatip schools (training schools for Muslim clerics) increased (Heper 2011). However, on $27^{\text {th }}$ May 1960, a military coup took place. Worsening economic conditions had made the DP increasingly unpopular and Kemalist military officers took the opportunity to attempt to protect the Republican tradition. Though a minority RPP government was returned in the 1961 elections, the 1965 elections saw the rise of the Justice Party (JP), a DP 
successor group. The JP were strongly pro-Western and sought to steer a middle ground between an increasingly left-leaning RPP and religious conservatives. During this time, imam hatip schools continued to grow and, further, women were also given access to them (Nohl 2008). Another military coup took place in 1980 following which all political parties were shut down (Heper 2011). However, the general trend away from Kemalism and leaning more towards an assertive Islamic stance continued in spite of the military's interventions. The 1980s saw the rise of the "Turkish-Islamic Synthesis", which asserted the inherently Muslim nature of Turkey and which began to influence the education system. For example, religious education was made compulsory in both primary and secondary schools during this period (Zurcher 2004).

The military intervened again through 1997's "post-modern coup", leading to the government's resignation. Their intention had been to reduce the number of imam hatip schools (Akboga 2015). Crucially, by extending basic compulsory education to eight years, the Security Council aimed to eliminate imam hatip middle schools (Nohl 2008). As we shall see below, the issues pertaining to extending schooling and the place of imam hatip schools are central to the current debates and disputes about education and religiosity.

The Age of the JDP

When the JDP initially came to power, it sought to present a modernising image by supporting European Union (EU) membership, implementing democratic reforms, and advocating peace with the Kurds and supporting minority rights in order to gain consent from different sections and groups within society (JDP Programme 2002). Even people from opposing positions began to believe that the JDP had found a middle ground between secularism and Islam (Göl 2009), and some saw the JDP as offering a way out of what was perceived as Kemalist elitism (Atasoy 2009) and towards a more heterogeneous society (Kadir 2014). This can be described as the JDP's initial attempt to construct a hegemonic alliance.

In education, the JDP initially pursued an inclusive and pluralist approach. From entering power in 2001, this was closely linked to a wider strategy of securing EU accession. The first major change to the education system began in 2002 with the EU-sponsored Support the Basic Education Programme that was intended to improve the conditions of primary school education in preparation in order to meet the associated conditions of EU membership. However, with the accession process stalling in the late 2000s and the JDP power becoming consolidated, the JDP abandoned its attempts to align its education system with the West and began a progressively more Islamic turn in education policy. During its first term of rule (2002-2007), the JDP did not take immediate action to lift the ban on the Islamic headscarf, nor did they make any radical changes with regards to religious education. However, after its second and third victories (2007 and 2011) consolidated the party's power, especially amongst rural and more religiously-minded voters, the JDP was encouraged to make alterations to increase the rise of religiosity in the public space (Kaya 2015). The party waited until its third term of office to make radical changes to the education system.

The 4+ was implemented immediately after the JDP was re-elected in 2011. It ostensibly extended the length of schooling from eight to twelve years and brought overall structural changes to the education system that mark it out as the most ambitious education reform since the early Republican era. Before 4+, the education system was based on eight years of schooling, 
divided into the primary and secondary levels, which did not allow pupils to leave basic education and attend any type of vocational schooling before having completed their eight years. 4+ separated the education system into three different levels, primary, middle and secondary, and paved the way for pupils to choose different types of compulsory schooling at the end of primary school. The school types officially include basic schooling, vocational schools and distance education. Nevertheless, in practice vocational schools mean imam hatip (religious) schools, as there are no other vocational schools that provide middle school education (Gün and Baskan 2014). The 4+ reform, therefore, allows pupils to enter imam hatip schools at the age of ten. Unsurprisingly, this move has been hugely unpopular with secular commentators (Egitim Is 2016).

In 2012, immediately before the 4+ legislation passed, the government claimed that the reform was intended to be more pluralistic and democratic than previous reforms (JDP 2012). However, critics suggested that the changes the government were suggesting were not designed to improve the education system but to spread the JDP's political and religious ideology (e.g., Inal and Akkaymak 2012). The expansion of imam hatip schools has become one of the key fault lines in this controversy, hence their centrality to this paper.

Imam hatip schools were first opened in 1924 to replace madrassas. There were only 29 such schools, initially designed solely to train imams (preachers) (Çakmak 2009); hence, they were seen as vocational schools. However, numbers grew from the 1950s and the link to preacher training was weakened. As we saw above, the 1997 coup sought to reverse this. However, the 4+ re-established imam hatip middle schools, which subsequently saw rapidly increasing enrolment.

\begin{tabular}{|l|l|l|}
\hline Academic Year & Student Number & Number of schools \\
\hline $2012-2013$ & 94467 & 1099 \\
\hline $2013-2014$ & 240015 & 1361 \\
\hline $2014-2015$ & 385830 & 1591 \\
\hline $2015-2016$ & 524295 & 1961 \\
\hline
\end{tabular}

Table 1: Imam Hatip Lower Secondary Schools (middle schools, age group: 10 to 14).

Adapted from: Ministry of National Education Strategy Development Presidency, National Education Statistics.

The JDP remains openly supportive of religious education, and the opening of imam hatip middle schools has provided religious education to pupils as young as ten years old. There has also been an increase in the number of religious courses in the national curricula. These recent changes suggest that the state has been using education policies to shape a new public ideology, as will be discussed in the following section.

Theoretical Framework: Hegemony, Politics and Educational Policy 
This article draws ideas from Gramsci's concepts of "hegemony" and "civil society" to portray the state's role in society and how education policies play an important part in maintaining the state's supremacy.

For Gramsci (1971), hegemony describes a situation where a social group or a class exercises "intellectual and moral leadership" to dominate opposition groups. This social group or class seeks to avoid, where possible, exercising control through coercion but rather seeks to shape the oppressed groups' 'common sense' through ideological means (Gramsci 1971). In this way, consent is counterposed to coercion (although elements of both always co-exist). Education is one of the tools to build a new common sense: by being educated within the dominant system, people's common sense develops in such a way as to consolidate and reinforce this system (Gramsci 1971). This has generated rich international literature on hegemony and education (e.g., Mayo 2010 and 2015; Pizzolato and Holst 2017). Hegemony, as Mayo argues, is an on-going process of power struggles: "it is never complete and open to negotiation and renegotiation" (Mayo 2010, 24), and education is seen as central to these processes.

In the context of Turkey, the importance of hegemony lies in helping us to understand how the ruling group uses cultural and moral values in education to promote its own ideology and to develop the type of hegemonic alliances that can sustain its power. The Turkish Gramscian tradition focuses on the replacement of a secularist hegemony with an Islamic one (e.g., Atasoy 2009; Tuğal 2009). This paper argues that education has been one of the key tools employed in this process to create this new hegemony. For the JDP to consolidate its hegemonic power, it was necessary to win legitimacy and consent among the Turkish population, or at the very least large sections of it. We argue that education has played a key role in securing this consent, in part because of the key role that education plays in civil society.

Civil society can be described as that part of the social system which is neither the coercive power of the state, nor the realm of the market and exchange. Rather, it is a range of institutions (both state and non-state) in which hegemonic power is exercised. Such institutions include education and social welfare services (often state institutions) but also the media, trade unions, religious bodies and voluntary organisations (see Altinors 2016; Heper \& Demirel 1996; Shukla 2009 for discussions of the media as civil society). This inclusion of state and non-state bodies led Gramsci to argue that the political state and civil society were not separate but "one and the same thing" (Gramsci 1971, 60).

Thus, the Gramscian concept of civil society refers to the cultural institutions of the state. Social institutions such as schools, the law and mass media, which are considered part of a civil society, are never neutral but rather serve the interests of the dominant class in order to generate consent and the cultural bedrock of power (Mayo 1994, 15). Civil society is "symbiotically connected to the state; and as the integral state, they produce hegemony together. Civil society is neither a necessarily progressive entity nor the sphere of freedom; it is rather the sphere of hegemony" (Altinors 2016, 74). For Gramsci, understanding civil society was critical because this was the space in which common sense was forged and, indeed, contested. In Turkey, Dikici-Bilgin $(2009,109)$ argues that civil society has become "a site for hegemonic struggles (...) as a counter-hegemonic force". Civil society can act as a sphere through which to organise opposition and create counterhegemonic movements. The JDP government, 
already dominant in political society, has been constructing, through the institutions of civil society, an alternative hegemony to the existing secularist hegemony. Within Turkish civil society, the concern of this article focuses specifically on the role of education unions and the media. These are just two elements of civil society, but in relation to educational issues they play a key role in determining how educational discourse is framed and therefore in determining how education reforms are able to play a hegemonic role in society as a whole.

Teacher unions are a key site of struggle regarding the meaning of education and accordingly this is a highly politicised space in Turkey. There are three main teachers' unions: Eğitim ve Bilim Emekçileri Sendikası (Egitim-Sen), Eğitimciler Birliği Sendikası (Egitim-Bir-Sen) and Türkiye Egitim, Ögretim ve Bilim Hizmetleri Kolu Kamu Çalışanları Sendikası (Türk- EğitimSen). There is a visible tension between these unions, especially between Egitim-Bir-Sen and Egitim-Sen. They hold strongly contrasting political views, which "is a determining factor in their attitudes towards the general policies and educational reforms" (Buyruk 2015, 157). Egitim-Sen is seen as a left-wing trade union and promoter of a secular and scientific education, and is Turkey's only Education International Affiliate (the international confederation of education unions). It has published various critical articles and reports about the 4+ education system. On the other hand, Egitim-Bir-Sen takes a different standpoint about 4+ and the education system as a whole. It is known for its traditional and conservative perspectives on education, views which coincide with those of the JDP. Türk-Eğitim-Sen is known for its nationalist and traditionalist perspectives, and accordingly this union's views align with those of the Nationalist Movement Party.

Also of considerable importance in framing educational policy discourse is the media, described by Mayo $(2015,11)$ as "a form of a public pedagogy; a vehicle for ideological influence". Indeed, Gramsci argued that the press was "the most dynamic part of the ideological structure" (Gramsci 1971, 381). In recent years, the Turkish government has been widely criticised on the international stage for its excessive control over the media and journalists, particularly those sources considered critical of the ruling party (Akser and Baybars-Hawks 2012; Freedom House 2014; BBC 2015; Deutsche Welle 2013). Private media groups have been targeted, such as Dogan Media Group, which owned the country's leading newspaper, Milliyet. It was fined and eventually forced to sell its holdings to a pro-government group (Freedom House 2014). After this, Milliyet "laid off important critical columnists". As Freedom House $(2014,5)$ notes, most mainstream newspapers "have become mouthpieces for the government" as hegemonic tools to consolidate the JDP's power (Altinors 2016).

Moreover, in the aftermath of the failed coup, the unions and media organisations were the first institutions to come under investigation by the government. Educators and journalists are amongst the two groups most likely to have experienced post-coup reprisals (dismissals, suspensions and sometimes imprisonment). This indicates that the media and the unions are key components in the battle of ideas in modern Turkey, and that these institutions within civil society cannot be seen to be separate from this on-going hegemonic struggle.

\section{Data Collection and Analysis}


This paper offers new data to examine the question of rising religiosity in Turkish schooling through reporting on data collected between 2013 and 2016. In this paper, we focus on the interviews that were carried out with teacher union members and journalists.

Teacher unions published a considerable amount of work on the 4+ reform, and some have played "important roles in the generation and implementation of education policies with the strategies that they developed" (Buyruk 2015, 147). Interviews were conducted with a total of seven union officials from three different unions. The roles of the participants in these unions were: three chairmen (General Secretary level), two district union presidents, and two senior union officers. At present, there are around 40 teacher unions in Turkey, but we selected the three biggest unions as presented above. One of these unions saw a large number of its members detained after the coup.

Conducting interviews with the mainstream newspapers in Turkey provided insights into the freedom of the media and into the extent to which the government has been monitoring how educational changes are reflected within the media. The media is essential for shaping the public's perception of changing reforms. Interviews were conducted with the lead education correspondents from five key newspapers. Two of these newspapers are known to be progovernment, two more liberal, and one pro-secularist. One had a number of its staff detained after the coup, but none were closed down.

It was challenging to access participants at first. To gain access, it is important to find contacts that can act as links. Once the contacts had been reached and an interview arranged with one of the participants, the rest followed. We employed a snowballing technique where every participant provided a reference to someone else they knew.

Given the febrile atmosphere, anonymity was a key issue, particularly as many of the interviewees were public figures. A considerable amount of information was offered in confidence and off-the-record. Prior to each interview, the confidentiality and anonymity of the participants was guaranteed. Both groups are referred to here as TUP (teacher union participant) or EDJ (education journalist) with a suffix number, as naming their union or newspaper would make their identification possible. The interviews lasted around 50 minutes and focused mainly on the changes the $4+$ had brought and, further, their views on educational policymaking in Turkey.

The data was analysed through thematic coding. Patterns in the interviews and documents were closely examined. The coding was completed manually and the transcripts divided into relevant categories and themes. The categories were reanalysed for recurring themes that helped us make sense of the data. Initially, the data was coded without reference to the Gramscian theoretical framework, which Braun and Clark (2006) refer to as inductive thematic analysis. The key themes were then analysed within a Gramscian theoretical framework, which provided us with a more detailed analysis of certain aspects of the data. Several themes were identified but this paper focuses only on the rise of religiosity, debates over the headscarf, expansion of new religious schools, and the configuring of the curriculum to promote religious education across all schools. 
Findings: The rise of religiosity

In this section, we focus on how religion and religious education are perceived by two polarised groups. Opponents of the 4+ reform have argued that the $4+$ is religiously oriented and aims to raise pupils with Islamic values. The supporters of the reform, however, responded to these claims by stating that educational reforms prior to the $4+$ were aimed at raising homogenous groups of pupils who were only taught secularist principles, which had led to the repression of Islam's heritage in Turkish society. As one interviewee put it: 'the previous (secularist) governments did not allow any room for people who had different ideologies and did not even let those people, especially women (due to their headscarves), take place in the public sphere' (TUP3). Similarly, some participants also expressed the view that the secularists alienated them and now it was their turn to participate in the public sphere. In both groups, religious and non-religious, there were many references to "us" and "them", which indicated the on-going battle between Islam and secularism through the use of language:

We (meaning women wearing headscarves) were not allowed to work in institutions of the state; we were not even allowed to attend universities. Now, thanks to the JDP party we can do whatever we want. They (the secularists) thought we could only cook and clean the house, they did not think that we had any opinions. One of the women's think tanks did not even let me in their meetings (TUP3).

Women who are practicing Muslims felt oppressed by the previous regime and the JDP stood by these 'victims'.

The JDP's political actions and its party ideology are based on several different discourses ranging from neo-conservatism, neoliberalism, Islamism, victimisation, to antilaicism. In this context, the JDP promoted a discourse of victimisation through which it has managed to "win the hearts" of the masses (Kaya 2015, 48). The female supporters of the JDP believe that the party is providing them justice. Many devout Muslims see the JDP as their saviour (Çınar 2018). Moreover, the JDP, by giving religiously-oriented women more opportunities in the public sphere, has gained women's consent. Many women, regardless of their beliefs, supported the JDP's decision to lift the headscarf ban in universities and state institutions. However, the JDP expanded the law and permitted the use of the headscarf in primary and secondary schools in the name of religious freedom. While some supported this policy change, others argued that introducing headscarf use in primary schools was an ideological tool for the government to condition children at an earlier age. For instance, Cin et al. (2018) show that religion and religious schools are used as an intervention strategy to increase girls' enrolment in primary schools in Eastern Turkey, as well as a tool with which to promote the neo-conservative agenda of the government.

Perhaps the most serious disadvantage of this policy change is the possibility of polarisation among students and teachers. In the context of Turkey, where the dominant religion is Islam, wearing headscarves has different connotations and signifies the level of devotion the students have. It can also indicate a political standpoint. The Islamic headscarf in Turkey has, therefore, become a source of polarisation and a symbol of a wider political struggle. It is important to note that in imam hatip schools, female students have already had the choice 
of wearing headscarves and most imam hatip school parents send their children to those schools to practice their religion.

The Imam Hatip School Debate

The government believes that imam hatip schools represent a necessary step in addressing the grievances of religiously conservative community and have called them "invaluable institutions that graduate generations of youth who vitalize Turkey's future" (Ozgur 2015, 27). In 2012, President Erdogan (Prime Minister at the time) openly declared that his, and his party's aim was to "raise religious youths" (Hürriyet 2012). As table one shows, there has been a strong increase in the number of imam hatip school and enrolment at the middle school level, with a smaller increase at the high school level.

During the interviews, there were two different opinions expressed on the imam hatip school issue. On the one hand, advocates of imam hatip schools identified a clear demand for these schools. However, on the other, opponents of the reform challenged the argument that the public wants/needs more imam hatip schools. As one of the participants explained:

They keep saying that there is this great need for imam hatip schools but we actually know that they had to close some down due to not having enough pupils. We know these things because we write articles, report about it every day. Go around your neighbourhood you will see how many imam hatip schools have recently been opened and how many pupils are actually attending these schools (EDJ3).

As we showed in tables one and two, many imam hatip schools were opened after the $4+$ reform was passed. Consequently, it has been debated as to whether there are more imam hatip schools now than are actually needed. Another participant was more vocal about the issue, reacting to all newly built imam hatip schools:

There are imam hatip schools everywhere now. Do we really need this many? Did anyone discuss whether children need religious education at the age of 10 ? Do they need to attend imam hatip schools as early as this? (EDJ2).

The imam hatip school debate brings up an important notion of Gramsci: 'organic intellectuals': "the dominant group's deputies exercising subaltern functions of social hegemony and political government" (Gramsci 1971, 118). In this light, imam hatip schools might be considered to be producing the organic intellectuals of the future, and considered central to the realisation of the JDP's bid for long-term hegemonic power. Indeed, it is argued by some respondents that imam hatip schools were designed for the sole purpose of creating an intellectual movement that promotes the JDP's ideological and political discourse. One participant said: 
By re-establishing imam hatip middle schools, the state helps spread these schools. The state should be impartial towards an issue like religion, but it is not. The political government that came to power is religiously rooted and they are raising new generations with their mentality (EDJ4).

However, people who come from religious backgrounds believe that the issue of imam hatip schools is one of freedom of choice and that the state has a responsibility to its citizens to provide as many imam hatip schools as are wanted (TUP4). One of the proponents of this position referred to the issue of school attendance by female pupils. The participant talked about how more traditional and conservative families in Turkey did not want to send their daughters to school beyond the primary level:

I see this (reopening of middle school level of imam hatips) as offering the option. Parents who want their children to have secular education can send them to basic schools. The state must provide the alternative, then it is up to its citizens to opt for this alternative or not. Turkey does not only consist of Istanbul and Ankara. In the East of Turkey, in small cities, there are many families who do not send their daughters to school due to not having the option of imam hatip middle schools (EDJ5).

Hence, apparently paradoxically, classic liberal ideas such as freedom of choice and women's rights are utilised to justify the strengthening of religious education, not typically part of the liberal "tool kit".

The participants who supported imam hatip schools naturally did not agree with the 1997 Basic Education Act, which sought to eliminate imam hatip middle schools. For instance, one interviewee said:

The $4+$ is not an imposition like the previous reform. Before the $4+$, the logic was that the pupils would have the same syllabus and all pupils would graduate with the same mentality (referring to Kemalism). Now, pupils can choose from different options. There are elective courses, vocational secondary schools, imam hatip secondary schools, there are lots of alternatives. It was not like this before (TUP2).

However, the claim that there are wider options can be questioned. The only difference in terms of offering alternative education routes is the reopening of imam hatip middle schools. Before the $4+$ there were still vocational secondary schools and imam hatip secondary schools.

Reconfiguring the curriculum: promoting religious education across all schools 
What we are seeing is not just the increased availability of the imam hatip option. Additionally, religious classes in basic schools have also increased in number. Prior to the 4+ reforms, there had only been introductory courses called Religion and Ethics where pupils supposedly learnt about ethics and general concepts of religion. As with the whole curriculum, the content of these courses were controlled by the MEB, and parents wishing their children to pursue further religious education had to send them to Quran Study Schools, as controlled by the Director of Religious Affairs. However, since the 4+ reform, pupils can also choose Quran as one of their classes in basic schooling. The main criticism of the reform is that it challenged the secular tradition in basic schooling:

There is not any difference between basic and imam hatip schools. In basic schools you can choose Quran and Arabic as elective courses. Both imam hatip and basic schools have to follow the same curriculum. But they are increasing the number of religious classes in basic schools and they are trying to phase out Atatürk's Principles and Revolution History classes in both schools. So, tell me how is this reform is not ideological? (EDJ2).

Of course, this is not a case of a lack of ideological direction to schooling being replaced by more explicit ideological intervention for the first time. That nearly 100 years after the Revolution schools are still teaching Atatürk's Principles points to the longstanding Kemalist ideological influence on schooling, and the curriculum as a site of contestation over the country's future trajectory.

Moreover, opponents of the reform have argued that many of the newly introduced elective courses (such as drama, law and justice, and media literacy) which appear to be aimed at enriching the curriculum and promoting diversity have not, in fact, been applied in most schools, resulting in curriculum diversity meaning little more than increased religious instruction. During the interviews, some participants noted that pressure is placed upon pupils and their parents by school managers to choose certain subjects (TUP1, 6, 7 and EDJ1, 2).

However, this was countered by another participant who rejected the claims about the reform forcing pupils to take religious classes.

Nobody is forcing anyone to take the elective Quran class. They are all elective classes after all. Why would this be against secularism? Secularism means separation between the state and religion. It does not mean running from religious education (TUP4).

Yet, what is clear is that there is still the compulsory religious class 'Religious Culture and Ethics' throughout the schooling system, and pupils with different beliefs do still have to attend these classes. Even though it is claimed that 'Religious Culture and Ethics' is aimed at 
teaching pupils about different religions, there are concerns that the course is actually designed to teach Sunni-Islam in spite of more than a quarter of the population being Alevis.

The government increased the number of compulsory religious classes in basic schools with the new reform (...) whether they accept it or not, it was one of the aims of the reform. These classes should be teaching about religion in general, but we do not know what happens in classrooms (EDJ3).

Even before the 4+ education reform was introduced, in 2010, the hours devoted to the Religion and Ethics course was increased, and instruction in this subject was introduced four grades earlier (from year four instead of year eight) (MEB 2012). In 2014, during the $19^{\text {th }}$ National Education Council, Egitim-Bir-Sen and the Ministry of Education suggested that the Religious and Ethics course should be introduced from year one onwards (Hürriyet 2014). During the interviews, some participants were critical that these religious courses did not include any reference to other Islamic traditions apart from Sunni-Islam (TUP1 and TUP 2, EDJ2). In the words of a teacher union official:

It might be true that the government tried to save the education system from its Kemalist structure, from the militarist understanding. Revoking national oath is a constructive step. When you look at the changes they are trying to make, they are discarding the homogenous Kemalist order, but they are also employing their own homogenous conservative agenda within the education system (TUP2).

The long tradition of Kemalist hegemony has been being replaced by the JDP's more Islamist hegemony. The rise of religiosity within the Turkish education system is a reflection of the on-going battle between secularism and Islam in the country and how this plays out in its education system. A representative from a religiously-oriented union openly stated that the previous education system did not include 'our moral and religious values and the secular principles swept away any Islamic heritage we have' (TUP5). They noted further:

Everything was built within secularist and positivist frameworks. This approach led religion, and anything related to tradition to fall into a secondary position. That is why we find the $4+$ valuable. Throughout the years, secularism and modernism acridly caused people to lose their values instead of bringing something beautiful to the table. This caused societal earthquakes. We find our new education system to be a reflection of our faith and our past (referring to the Ottoman Empire) (TUP5).

These statements indicate that the union's ideology is similar to that of the government, and further that there is a clear support for the Islamisation of the education system. Beyond 
the imam hatip issue, this extends to a move to make the curriculum of "regular" schools more Islamic than has hitherto been the case.

\section{Discussion and Conclusion}

This research highlights the contested nature of the reforms and the extent to which participants have sought to support or challenge the government's agenda. In this final section, we seek to demonstrate how teacher unions and media interests have been mobilised or marginalised by the state in order to either promote its own agenda or to silence critical discourse.

Our analysis of the $4+$ highlights the key role played by education in hegemony building in Turkey. This is not unique to the JDP administration and the 4+ reforms, but rather it is important to see education as a site of contestation in which ideas about the Turkish identity have been struggled over for many years. What we argue is that the $4+$ reforms mark a specific phase in this process of struggle whereby the balance of forces has shifted decisively in favour of the current ruling party. In being able to promote these reforms, the JDP is in turn able to consolidate its position of strength.

With regards to the education unions, several of the interview participants stated that only one teacher union's opinion was taken into consideration during the implementation of the reform process and that this union is known to have a close relationship with the government (Buyruk, 2015). In contrast, union groups who opposed the reform felt like their opinions were ignored.

These participants emphasised the fact that the government can ask as many people's opinions as it wants, but at the end of the day if they do not take those (opposing) opinions into consideration, the government cannot really make any representations about civic participation.

One of the major teacher unions was founded immediately after the JDP came to power in order to reflect a new educational discourse. Its membership has increased substantially over the years, and this union has become the only effective policy actor in developing educational policies. Most current school leaders are members of this union, some of whom have argued that patronage plays a key role in the Turkish education system whereby career progression depends on membership of the pro-government union (Bascia and Stevenson 2017).

Equally, the main media outlets are owned by a few large holding companies and often have outside business interests. In many cases they refrain from excessive criticism of the government (Freedom House 2018). Thus, patronage is used to build hegemony and rewards compliance.

Of course, there are spaces for resistance and there are unions who previously known to hold protests and marches against the 4+ or the government's religious inclinations towards education. There are also journalists writing more critically about the government's policies and reforms. However, the governmental pressure applied to these opposition groups has intensified since the failed coup. For some of its more critical respondents, the government's approach towards such opposition has created a climate of fear, resulting in real constraints on the words and actions of journalists and educators alike.

In recent years, it has been contended that the government's control over media organisations, particularly newspaper publishers, has increased (Freedom House 2014). It could 
be argued that, by controlling the media, the JDP monitors the ways in which educational changes are reflected in the media, as the press the becomes "the most dynamic part of the ideological structure"(Gramsci 1971, 381). This illustrates our argument that in Turkey the state and the civil society are far from autonomous in their relationship and, to use Gramsci's phrase, they are "one and the same thing" (Gramsci 1971, 60).

This privileging of particular voices (pro-government unions and sympathetic journalists), whilst seeking to marginalise and exclude others, provides an insight into how hegemonic discourses are constructed within civil society. What is clear is that the Turkish state has worked strategically within key institutions in civil society in order to frame the debate about the Turkish education system and reorientate it in ways that promote the process of Islamisation. The process of Islamisation, with its appeal to large sections of conservative society, is central to securing the power base of the ruling party. In this way, we can see 'hegemony building' as a process that takes place at multiple levels and in myriad forms. The JDP's 4+ education reforms are part of a hegemonic project intended to assert ideological power and influence within Turkish society. However, the reforms are themselves the outcome of an ideological struggle in which state power has been used to mobilise specific discourses and to marginalise others. Education plays a key role in civil society, whilst simultaneously being the outcome of civil society struggles.

This data also highlights the iterative role of education in hegemony building in Turkey in which distinctive processes act in mutually reinforcing ways. The promotion of a religiously conservative education system speaks directly to the grievances of large sections of society who previously felt ignored by Kemalism. Here, education reforms have acted as a focus around which this community, both in civil society institutions and in the wider population, can be mobilised. The reforms, therefore, play a key role in broadening the hegemonic alliance that underpins the JDP's support. However, imam hatip schools and the 4+ curriculum reforms also help embed a worldview which promotes Islam as the new common sense. In this respect, the reforms can be seen as building an ideological base intended to sustain support for a political party that has always been explicitly Islamic, i.e., non-secular. Each of these two elements reinforces the other by promoting Islam as the new common sense and providing the education system that Islamism demands. It is these mutually reinforcing processes that underpin what Gramsci described as 'the fortresses and earthworks' $(1971,238)$ of civil society, and hence of hegemonic power.

In conclusion, we have sought to demonstrate how education is central to the JDP's hegemonic project. Our argument is that education is being developed as a form of hegemonic power in Turkish society, but it is itself the outcome of struggles in civil society for hegemonic leadership. In Gramscian terms, schools are becoming a key tool in allowing the JDP to develop its organic intellectuals (Gramsci 1971) - a cadre of young JDP supporters capable of promoting the ideas of the movement within their communities. They are also the means through which to win the support of large sections of the population as part of a hegemonic alliance. They are the product of an alliance in which key sections civil society (unions and the media) have been mobilised to win support for education reforms.

Thus, the paper adds to a growing body of literature on Gramsci and the relevance of his ideas in contemporary education policy contexts. It illustrates the argument that education 
acts as one of the key ideological tools through which governments can promote neoconservative ideologies to future generations, but is itself a site of contestation (Apple 2006).

Finally, the relationship between the state and civil society is not autonomous, and civil society is certainly underdeveloped. This is evidenced by the high levels of coercion and authoritarian governance that are a feature of the modern Turkish state. The JDP government makes little effort to seriously engage with civil society in a wider context but rather relies on building alliances with networks of sympathetic organisations such as government-aligned media and trade unions. Civic participation is reduced to co-option of certain groups in order to strengthen the state's hegemonic alliance, whilst opposition groups are at best marginalised, but in some cases are confronted more directly (a phenomenon that has become more transparent as the Turkish state has responded to the July 2016 coup). While the state is forming strategic alliances, it also seeks to close down the spaces for counterhegemonic discourse, and as indicated this situation has been exacerbated in the period following the coup.

\section{Disclosure statement}

No potential conflict of interest was reported by the authors.

\section{References:}

Altinors, G.2016. Minarets and Golden Arches: State, Capital and Resistance in Neoliberal Turkey. University of Nottingham, Ph.D Thesis. [Online] Available at: http://eprints.nottingham.ac.uk/37869/.

Akboga, S. 2015. The expansion of compulsory education in Turkey: local and world culture dynamics. Compare: A Journal of Comparative and International Education. 46 (5), 1-22. 
AK Parti.2012.Eğitim sisteminde reform. [Online] Available at:

https://www.akparti.org.tr/site/haberler/egitim-sisteminde-reform/24146\#1

Akser, M., and Baybars-Hawks, B. 2012. "Media and Democracy in Turkey: Towards a Model of Neoliberal Media Autocracy". Middle East Journal of Culture and Communication 5,302-321.

Atasoy, Y. 2009. Islam's Marriage with Neoliberalism: State transformation in Turkey. New York: Palgrave Macmillan.

Braun, V., and Clarke, V. 2006. "Using thematic analysis in psychology". Qualitative Research in Psychology 3(2), 77-101.

BBC. 2015. Turkey social media ban raises censorship fears. [Online] Available: http://www.bbc.co.uk/news/world-europe-32204177.

Buyruk, H. 2015. "Current developments in school education in Turkey: Education 'reforms' and teacher trade union responses". FORUM 57 (2): 147-165.

Cin, F. M., Karlıdağ-Dennis, E., and Temiz, Z. (2018). Capabilities-based gender equality analysis of educational policy-making and reform in Turkey. Gender and Education, 1-18.

Cumhuriyet Gazetesi. 19.12.2016. Okullarda ilk Ders: 15 Temmuz Darbe Girisimi. [Online] Available at:

http://www.cumhuriyet.com.tr/haber/turkiye/601925/Okullarda_ilk_ders_15_Temmuz_darb e_girisimi.html.

Çakmak, D. 2009. Pro-Islamic Public Education in Turkey: The Imam-Hatip Schools. Middle Eastern Studies 45(5), 825-46.Turkish Studies 19, 176-197.

Çınar, M. 2018. Turkey's 'Western' or 'Muslim' identity and the AKP's civilizational discourse.

Deutsche Welle 2013. Turkish Media under pressure ahead of election. [Online] Available http://www.dw.com/en/turkish-media-under-pressure-ahead-of-election/a-18475089

Dikici-Bilgin, H. 2009. Civil society and state in Turkey: A Gramscian perspective. Gramsci and Global Politics Hegemony and Resistance. Ed. Mark McNally \& John Schwarzmantel. London: Routledge.

Egitim Is. 2016. MEB İstatistikleri 4+4+4 Egitim Sisteminin Yarattigi Yikimi Ortaya Koydu. [Online] Available at: http://www.egitimis.org.tr/guncel/sendika-haberleri/meb-istatistikleri-44-4-egitim-sisteminin-yarattigi-yikimi-ortaya-koydu-1632/\#.WH9Rh7GcaAl.

Freedom House.2014. Democracy in Crisis: Corruption, Media, and Power in Turkey-a Freedom House Special Report.

Gramsci, A. 1971. Selections From The Prison Notebooks. New York: International Publishers.

Göl, A. 2009. The identity of Turkey: Muslim and secular. Third World Quarterly 30, 795-811. 
Gün, F., and Baskan, G. 2014. New education System in Turkey $(4+4+4)$ : A critical outlook. Procedia - Social and Behavioral Sciences 131, 229-235.

Güven, I. 2005. The impact of political Islam on education: the revitalization of Islamic education in the Turkish educational setting. International Journal of Educational Development 25, 193-208.

Heper, M., and Demirel, T. 1996. The press and the consolidation of democracy in Turkey. Middle Eastern Studies 32(2), 109-123.

Heper, M. 2011. Turkiye'nin Siyasal Hayati. Istanbul: Dogan Egmont Yayincilik ve Yapimcilik.

Hürriyet Gazetesi.2.2.2012. Dindar Gençlik Yetistirecegiz. [Online] Available at http://www.hurriyet.com.tr/dindar-genclik-yetistirecegiz-19825231.

Hürriyet Gazetesi.7.12.2014. Ilkokul 1'lere Zorunlu Din Dersi. [Online] Available at: http://www.hurriyet.com.tr/ilkokul-1-lere-zorunlu-din-dersi-27724351.

Hürriyet Gazetesi.19.09.2016. Ilk Ders 15 Temmuz.[Online] Available at: http://www.hurriyet.com.tr/ilk-ders-40227182.

Inal, K., and Akkaymak, G. 2012. Neoliberal Transformation of Education in Turkey: Political and Ideological Analysis of Educational Reforms in the Age of the AKP. New York, Palgrave Macmillan.

Kaplan, S. 2006. The pedagogical state: Education and the politics of national culture in post1980 Turkey. Stanford: Stanford University Press.

Kaya, A. 2015. Islamisation of Turkey under AKP rule: Empowering family, faith and charity. South European Society and Politics 20(1), 47-69.

Mayo, P. 2010. Gramsci and Educational Thought. Chichester: Wiley-Blackwell.

Mayo, P. 2015. Hegemony and Education Under Neoliberalism: Insights from Gramsci. New York: Routledge.

Milli Egitim Bakanligi.2012. 12 Yil Zorunlu Egitim Sorular-Cevaplar. (Twelve Years Compulsory Education Questions and Answers). Ankara.

Milli Egitim Bakanligi.2016. [Online] Available at: http://www.meb.gov.tr/okullar-15-temmuzdemokrasi-zaferi-ve-sehitleri-anma-etkinligiyle-acilacak/haber/11877/tr.

New York Times. 15,000 more public workers are fired in Turkey crackdown. Timur, Safak and Nordland, Rod. 22.11.2016. [Online] Available at:

http://www.nytimes.com/2016/11/22/world/europe/turkey-erdogan-coup-fired.html?_r=0

Nohl, A.M. 2008. The Turkish education system and its history. In A.M. Nohl, A. AkkoyunluWigley \& S. Wigley, eds. Education in Turkey. Munster: Waxmann. 
Ozgur, I. 2015. Islamic Schools in Modern Turkey: Faith, Politics, and Education. Cambridge: Cambridge University Press.

Pizzolato, N., and Holst, D. 2017. Gramsci: A Pedagogy to Change the World. New York: Springer.

Sabah Gazetesi.19.9.2016. Okullar Acildi!llk Ders:15 Temmuz. [Online] Available at: http://www.sabah.com.tr/gundem/2016/09/19/okullar-acildi-ilk-ders-15-temmuz.

Shukla, N. 2009. Constructing Global Civil Society from Below: A case study of learning global citizenship in the Save the Narmada Movement, India. Institute of Education, University of London. Ph.D Thesis. [Online] Available at: http://discovery.ucl.ac.uk/10019925/1/SHUKLA\%2C\%20N Redacted.pdf.

Talim ve Terbiye Kurulu 2010. Din Kültürü ve Ahlak Bilgisi Dersi (4-8. Siniflar) Ögretim Programi. [Online] Available at: http://ttkb.meb.gov.tr/program2.aspx.

Tugal, C. 2009. Passive Revolution: Absorbing the Islamic Challenge to Capitalism. Stanford: Stanford University Press.

Zurcher, E.J. 2004. Turkey : A Modern History. London: I.B. Tauris. 